need for routine sexual health testing and for future studies to better understand which MSW sub-populations are most at-risk. Disclosure of interest statement The ACCESS Sexual Health Services Network is funded by the NSW Ministry of Health, Victorian Department of Health, Australian Capital Territory Department of Health, and the Northern Territory Department of Health.

\section{P14.26 ANALYSIS OF RISK FACTORS INCIDENCE OF SEXUALLY TRANSMITTED INFECTIONS IN THE WOMEN INDIRECT SEX WORKERS IN MATARAM CITY, INDONESIA. 2012}

IK Mulyawan, Tris Cahyoso. Distric Health Office of Mataram, Indonesia

\subsection{6/sextrans-2015-052270.538}

Background Sexually transmitted infections are a public health problem in all countries, including Indonesia. The estimated number of people exposed to a sexually transmitted infection that can be treated approximately more than 30 million cases annually. In Mataram City 2011, found as many as 896 new cases of sexually transmitted infections. Women indirect sex workers have an important role in the spread of sexually transmitted infections and HIV-AIDS cases increased.

Research methods Design study was a cross sectional with a total sample of 66 women indirect sex workers. Risk factor of STIs is age of first sex, ever having sex, the number of customers per day, use of condoms, clean hands after sex, change underwear after sex, alcohol consumption habits and the habit of consuming drugs. Potential risk factors were explored using a structured questionnaire of the month from May to June 2012. Data were analysed using, bivariable and multivariable statistics.

Results From the bivariable analysis, risk factors for STIs were ever having sex (OR 2.33, CI 5.15-1:05), not using condoms (OR 3.13, CI: 1.36 to 7.20) and the number of customers per day (OR 2.60, CI: 1.13 to 6.01). Multivariable analysis showed that the risk factors that influence the incidence of sexually transmitted infections are not using condoms (adjusted OR 6.55, CI 1.83 to 23,43 ) and the number of customers per day (adjusted OR 5.01, CI 1.41 to 18.29).

Conclusion Not using a condom in serving customers in women indirect sex workers be risk factors for STIs. Need an effort to monitor the prevalence of sexually transmitted infections continued cooperation and support of stakeholder in pressing the prevalence of STIs.

\section{P14.27 FEMALE SEX WORKERS (FSW) IN BA RIA - VUNG TAU, VIETNAM: SOCIO-DEMOGRAPHIC CHARACTERISTICS AND RISK BEHAVIOURS}

${ }^{1} \mathrm{~T}$ Nguyen, ${ }^{1} \mathrm{D}$ Stewart, ${ }^{2} \mathrm{MK}$ Bui, ${ }^{3} \mathrm{TNH}$ Dang. ${ }^{1}$ School of Medicine, Griffith University; ${ }^{2}$ HIVI AIDS Prevention Centre of Ba Ria - Vung Tau, Vietnam; ${ }^{3}$ Preventive Medicine Centre of Ba Ria - Vung Tau, Vietnam

\subsection{6/sextrans-2015-052270.539}

Background FSWs are a high-risk population group for the transmission and acquisition of STIs and HIV. This research investigated socio-demographic characteristics and risk behaviours among FSWs in Ba Ria - Vung Tau, Vietnam.

Methods Data were collected using a cross-sectional survey of 420 direct/indirectly employed FSWs between January-May, 2014, from 2 cities/6 districts in Ba Ria - Vung Tau. FSWs were interviewed using a structured questionnaire and biological samples taken and tested for STI/HIV. Data were entered (Epidata 3.1) and analysed (SPSS 20.0) using univariate and multivariate analyses to investigate the associations between STIs and riskrelated factors.

Results 166 direct and 254 indirect FSWs participated in the survey, with a median age of 27 years, within a range of 18-43 years. Many (43.3\%) had minimal education (grade 5 or less). Most claimed religious affiliation (90.5\%) and 91.7\% were of Kinh ethnicity. At $63.1 \%$, the unemployment rate before becoming FSWs was high. There were significant differences between direct/indirect types of FSWs in terms of: education levels (OR $=2.46,95 \% \mathrm{CI}: 1.65-3.67, \mathrm{p}=0.001)$; marital status, including married or cohabitating (OR $=2.14,95 \%$ CI: $1.43-3.207$, $\mathrm{p}=0.001)$; unemployment before becoming FSWs $(\mathrm{OR}=2.36$, 95\% CI: 1.54-3.63, $\mathrm{p}=0.001)$; low income $\leq \mathrm{A} \$ 200(\mathrm{OR}=$ 3.74 , 95\% CI: $1.83-7.65, \mathrm{p}=0.001)$; and number of paying clients in the last month $>15(\mathrm{OR}=24.88,95 \% \mathrm{CI}: 14.73-$ 42.01, $\mathrm{p}=0.001)$. Inconsistent condom use with regular and new clients was $21.8 \%$ and $15.2 \%$ respectively. Most (89.0\%) FSWs performed oral sex, also a high proportion $(82.4 \%)$ of them consumed alcohol. Nearly half (48.3\%) have had sex when drunk. Regarding drug use, 23.4\% FSWs have used drugs and 26.1\% have clients who use or inject drugs.

Conclusions FSWs in Vietnam need targeted intervention programs and improved services to prevent HIV and STIs infection. Administrative and political support for improved health education and services are required to prevent the epidemic from spreading.

\section{P14.28 SEXUAL TRANSMITTED INFECTIONS AND RISK FACTORS AMONG FEMALE SEX WORKERS IN BA RIA - VUNG TAU, VIETNAM}

${ }^{1} \mathrm{~T}$ Nguyen, ${ }^{1} \mathrm{D}$ Stewart, ${ }^{2} \mathrm{MK}$ Bui, ${ }^{3} \mathrm{TNH}$ Dang. ${ }^{1}$ School of Medicine, Griffith University; ${ }^{2} \mathrm{HIV} /$ AIDS Prevention Centre of Ba Ria - Vung Tau, Vietnam; ${ }^{3}$ Preventive Medicine Centre of Ba Ria - Vung Tau, Vietnam

\subsection{6/sextrans-2015-052270.540}

Introduction Sexually transmitted infections (STIs) continue to be a major concern in public health because of their high incidence and prevalence. STIs are also a major problem for FSWs in Vietnam. The purpose of the research is to determine the prevalence of STIs and risk-related factors in Ba Ria - Vung Tau, Vietnam.

Methods Data were collected using a cross-sectional survey of 420 direct and indirect FSWs between January-May, 2014, from 2 cities and 6 districts in Ba Ria - Vung Tau. FSWs were interviewed using a structured questionnaire and biological samples taken and tested for HIV. A database was created using Epidata 3.1 software and analysed using the SPSS 20.0 statistical package. Univariate and multivariate analyses were used to investigate the associations between STIs and risk-related factors.

Results Prevalence were $6.9 \%$ for Syphilis, 7.9\% for Gonorrhoea (GC), $16.4 \%$ for Chlamydia (CT) and $21.4 \%$ for any one of the STIs (GC/CT). Increased risks for GC/CT were associated with age of first sexual intercourse $\leq 18$ (OR 3.57, 95\% CI: $2.11-$ $6.06, \mathrm{p}=0.011)$; number of paying clients in the past month $>15(\mathrm{OR}=2.16,95 \% \mathrm{CI}: 1.34-3.46, \mathrm{p}=0.001)$; inconsistent condom use with regular customers $(\mathrm{OR}=1.98,95 \% \mathrm{CI}: 1.17-$ $3.37, \mathrm{p}=0.010)$ and new customers $(\mathrm{OR}=2.18,95 \% \mathrm{CI}$ : $1.20-3.94, \mathrm{p}=0.009)$; and unprotected sex with non-paying partners $(\mathrm{OR}=3.89,95 \% \mathrm{CI}: 1.51-10.00, \mathrm{p}=0.003) . \mathrm{A}$ 